\title{
Hair as a tool for identification of predators and prey: a study based on scats of jaguars (Panthera onca) and pumas (Puma concolor)
}

\author{
Fernanda C. Souza ${ }^{1,4}$, Fernando C.C. Azevedo ${ }^{2,3 *}$ \\ ${ }^{1}$ Universidade Federal de Minas Gerais, Instituto de Ciências Biológicas, Programa de Pós-Graduação em \\ Ecologia, Conservação e Manejo da Vida Silvestre, Belo Horizonte, MG, Brasil. \\ ${ }^{2}$ Universidade Federal de São João del Rei, Programa de Pós-Graduação em Ecologia, Departamento de \\ Ciências Naturais, São João del Rei, MG, Brasil. \\ ${ }^{3}$ Instituto Pró-Carnívoros, Atibaia, Brasil. \\ ${ }^{4}$ Universidade Federal de Lavras, Programa de Pós-Graduação em Ecologia Aplicada, Caixa Postal 3037 - \\ CEP 37200-000, Lavras, MG, Brasil. \\ *Corresponding author: Fernando C.C.Azevedo, e-mail:fazevedo@ufsj.edu.br
}

SOUZA, F.C., AZEVEDO, F.C.C. Hair as a tool for identification of predators and prey: a study based on scats of jaguars (Panthera onca) and pumas (Puma concolor). Biota Neotropica 21(1): e20201044. https://doi. org/10.1590/1676-0611-BN-2020-1044

\begin{abstract}
Microscopic hair identification is a non-invasive, simple, and economical method applied in scientific studies to identify mammal species. In ecology, this method is used mainly in mastofaunistic inventories and dietary studies. In the last decade, the number of dietary studies using the microscopic identification of hairs has grown substantially, but the application of this technique as a tool for the identification of both predators and prey species is still scant. Thus, the aim of this study was to identify predator and prey hairs in scat samples from the two largest species of carnivores in the Neotropical region, the jaguar (Panthera onca Linnaeus, 1758) and the puma (Puma concolor Linnaeus, 1771). We examined a total of 100 scat samples being 50 from the Pantanal of Mato Grosso do Sul and 50 from the Atlantic Forest of Paraná. We used different identification categories that included the hair microscopic and macroscopic identification, as well as the use of hooves and nails present in the scats associated with tracks and kills found in the field. We identified 57 prey items in the Pantanal samples and 61 in the Atlantic Forest samples. Predator's hairs were identified in 34\% of Pantanal samples and in 46\% of Atlantic Forest samples. The combination of hair microscopic and macroscopic characteristics was efficient in the identification of different taxonomic levels, with most identifications reaching the level of the species. However, the methodological protocol for microscopic hair identification was not fully effective in obtaining all the microstructural patterns of the studied mammals. Adjustments in the technique are necessary to differentiate microstructural characteristics of species belonging to the same family. We recommend macroscopic identification of scat content items (hairs, hooves or nails) of both prey and predators to be used to complete the microscopic hair identification technique in dietary ecological studies.
\end{abstract}

Keywords: Macroscopic identification; Microstructure hair; Tricology; Guard-hair; Predator hairs; Brazil. 


\title{
Pelos como ferramenta de identificação de predadores e presas: um estudo baseado em fezes de onças-pintadas (Panthera onca) e pumas (Puma concolor)
}

\begin{abstract}
Resumo: A identificação microscópica do pelo é um método não invasivo, simples e econômico, aplicado em estudos de identificação de várias espécies. Em ecologia, esse método é usado principalmente em inventários mastofaunísticos e estudos de dieta. Na última década, a identificação microscópica de pelos em estudos de dieta tem crescido substancialmente, porém ainda conhecemos muito pouco sobre o uso das características microscópicas e macroscópicas dos pelos para identificação tanto de presas quanto de predadores. Assim, o objetivo deste estudo foi identificar pelos de predadores e presas em amostras fecais das duas maiores espécies de carnívoros da região Neotropical, onças (Panthera onca Linnaeus, 1758) e pumas (Puma concolor Linnaeus, 1771). Foram examinadas um total de 100 amostras de fezes, provenientes do Pantanal de Mato Grosso do Sul e da Mata Atlântica do estado do Paraná, sendo 50 amostras de cada local. Utilizamos diferentes categorias de identificação que incluíam a identificação microscópica e macroscópica do pelo, bem como o uso de outros vestígios como cascos e unhas presentes nas fezes e pegadas e carcaças encontradas em campo. Nós identificamos 57 itens de presas nas amostras do Pantanal e 61 itens de presas nas amostras da Mata Atlântica. Pelos dos predadores foram identificados em 34\% das amostras do Pantanal e 46\% das amostras da Mata Atlântica. A combinação de características microscópicas e macroscópicas dos pelos foi eficiente na identificação de diferentes níveis taxonômicos, com a maioria das identificações atingindo o nível da espécie. No entanto, o protocolo metodológico de identificação microscópica dos pelos não foi totalmente eficaz para obter todos os padrões microestruturais dos mamíferos estudados. São necessários ajustes na técnica para diferenciar características microestruturais de espécies pertencentes à mesma família. Recomendamos que a identificação macroscópica de itens alimentares (pelos, cascos ou unhas) tanto de presas quanto de predadores seja usada para completar a técnica de identificação microscópica dos pelos em estudos de ecologia alimentar..
\end{abstract}

Palavras-chave: Identificação macroscópica; Microestrutura do pelo; Tricologia; Pelos-guarda; Pelos de predadores; Brazil.

\section{Introduction}

Populations of carnivore species are vital in the dynamic of their communities, exerting a direct influence on prey density or indirect in the plant community (Terborgh 1992, Borer et al. 2005). This top-down effect is based on the trophic cascade model in which the presence of predators affects the regulation of population density at other trophic levels (Terborgh et al. 2001). In this sense, felines are considered key species within an ecosystem because their presence controls the population size of their available prey and their absence causes population imbalance at other trophic levels (Schonewald-Cox et al. 1991). In addition, the conservation of feline species is crucial for biodiversity protection, as they require large areas with diverse habitat types and prey and the protection of these areas increases the chance of survival of other species (Carroll et al. 2001). Indeed, felines are considered bioindicators of the environment and studies related to ecological aspects of this group are important for the conservation of biodiversity (Santos et al. 2019).

Knowledge about dietary habits contributes for the understanding of ecological processes necessary for the protection of biodiversity, such as reproductive and social behavior, distribution, population density and habitat use (Juarez \& Marinho-Filho 2002, Bueno \& Motta-Junior 2004, Azevedo 2008). For this purpose, fecal screening methods and hair microstructure analysis have been conducted in studies on dietary ecology of felines (Chakraborty \& Chakraborty 1996, Martins et al. 2008, Tortato 2009, Perilli et al. 2016, Tirelli et al. 2018). The analysis of internal hair morphology using optical microscopy is a simple and economical noninvasive method applied in several species' identification studies (Dagnall et al. 1995, Wolfe \& Long 1997, Alberts et al. 2017, Felix et al. 2019, Mandoreba et al. 2019). In predator dietary studies, bone and tooth fragments found in fecal specimens may have little diagnostic value because they are often damaged due to intense fragmentation due to chewing (Chehébar \& Martin 1989). Thus, hair identification in scat samples can increase species identification accuracy, as hairs are less damaged in the digestive process (Quadros \& Monteiro-Filho 1998). However, this technique has limitations in the identification of feline hair, showing a high overlap in morphological characters between different species (Vanstreels et al. 2010, Rinaldi et al. 2015). This overlap occurs mainly when considering the morphological differences between small cats (Alberts et al. 2017).

Studies involving microscopic identification of hair spread around the world, bringing scientific and technical advances to the method, with the creation of keys and regional identification guides (Walllis 1993, Quadros \& Monteiro-Filho 2010, Alberts et al. 2017). In the Neotropics, there has been an increasing number of studies involving the mammalian capillary microstructure (Rinaldi et al. 2015, Alberts et al. 2017, Tirelli et al. 2018). Consequently, the use of microscopic identification of hair in scat samples have increased in recent years (Rinaldi et al., 2015, Alberts et al., 2017, Kshettry et al., 2018, Tirelli et al., 2019). However, the application of this technique as a tool for the identification of both predators and prey species is still scant. Thus, the objective of this study was to use the technique of microscopic identification to identify hairs of predators and prey from scat samples of the two largest carnivores species in the Neotropics, jaguars (Panthera onca Linnaeus, 1758) and pumas (Puma concolor Linnaeus, 1771) from two different sites in Brazil, South America. 


\section{Material and methods}

Our study was part of two projects conducted from 2002 to 2005 in the Pantanal region and from 2012 to 2013 in the Atlantic Forest, Brazil, to investigate jaguar and puma food habits, respectively. Our first study site was a $150 \mathrm{~km}^{2}$ working cattle ranch/wildlife reserve comprised of wetlands habitats, seasonally inundated grasslands and woodlands, in the southern region of Mato Grosso do Sul State $\left(20^{\circ} 05^{\prime} \mathrm{S}\right.$ and $\left.56^{\circ} 36^{\prime} \mathrm{W}\right)$. Both jaguars and pumas occurred in this site. The second site was a 50 $\mathrm{km}^{2}$ private area comprised of scattered fragments of Atlantic forest embedded in a matrix of agricultural land use interspersed with human habitats comprising on the northern region of Paraná State $\left(23^{\circ} 35^{\prime} \mathrm{S}\right.$ e $52^{\circ} 20^{\prime} \mathrm{W}$ ). It is highly probable that only pumas occurred in this site. The closest known jaguar population is located at approximately 250 $\mathrm{km}$ in the Iguaçu National Park, and movement of jaguars towards our surveyed area is very unlikely due to the lack of forested habitat in between those areas.

\section{Scat analysis}

We collected scats opportunistically on trails and roads in both study sites. Only scats associated with jaguar and puma's tracks or kills were included for the purpose of our analyses. Fifty (50) samples were randomly selected from a pool of samples from each study site ( $\mathrm{n}=149$, Pantanal; $\mathrm{n}=82$, Atlantic Forest) and screened to test the method to identify prey and predator hairs through slides of cuticular impression and medullary preparation. We dried scats at $72^{\circ} \mathrm{C}$ for $24 \mathrm{~h}$. After that, we immersed scats in water for $24-48$ hours until soft. Then we washed and broke up scats with running water through a fine mesh sieve. Food contents were identified to families, genus, and species using macroscopic and microscopic characteristics of hair, nails, and hooves via comparison with reference material (Azevedo 2008).

A portion of each sample went through the screening process and the hair found was stored in containers and labeled. The hair was cleaned with ethyl alcohol and dried on absorbent paper. We prepared hairs and analyzed the medullary structures and cuticle scale patterns following Quadros and Monteiro-Filho (2006a) with some few adaptations. For the medullar preparation, we added hydrogen peroxide plus commercial ammonia solution and bleaching powder. Thus, in the case of thin hairs, we placed those in hydrogen peroxide 30 volumes plus commercial ammonia solution and bleaching powder for 90 minutes, so the hair color is washed and hair becomes transparent. Thick hairs of whitelipped and collared peccaires (Tayassu pecari Link, 1795; Pecari tajacu Linnaeus, 1758), capybara (Hydrochoerus hydrochaeris Linnaeus, 1766), paca (Cuniculus paca Linnaeus, 1766), and giant anteater (Myrmecopha tridactyla Linnaeus, 1758) were placed in 40 volumes hydrogen peroxide, commercial ammonia solution and bleaching powder for 100 minutes. Transverse cuts in the hair shield were made on thicker hairs, thus allowing better penetration of the solution used in the discoloration. After these procedures, the hair was washed in water and permanent slides were made using Entelan or the colorless enamel as mounting medium. For the observation of cuticle scale patterns, the already cleaned hairs were placed on a slide covered with colorless enamel or commercial base, which was previously dried between 15 and 20 minutes. The time varied in relation to the temperature and humidity of the place where the slides were prepared. After this procedure, hairs were placed on the slide and pressed between two wooden boards in a vise, thus obtaining the cuticular impression. The impressions of the hair on the enamel stayed at least 30 minutes drying and after this time the hair was removed from the slides. Predator's hairs were identified by the same procedures used to make slides for prey species. When predator hairs could not be identified by the cuticular and medullary patterns together, we used some macroscopic characteristics in the identification, such as shape, thickness, size, or bandage color. Feline hairs can be found together with hairs of its prey because of their self-cleaning behavior when the hair is ingested, thus allowing its identification in the scats (Eckstein \& Hart 2000). Hairs that could not be identified as predator hair were also included in the study because scats were associated with predators' tracks or kills.

Cuticle scale patterns and medulla structure were visualized under a light microscope with magnifications of 100, 200, and 400x. Photomicrographs were obtained using the Image - Pro Plus software and camera attached to an Olympus BX51 microscope. For a better understanding of the variation in patterns found along the hairs, we took photos of the cuticular scales on the bulb (most proximal part of the hair), shaft (part between the bulb and hair shield), and shield (most distal end of the hair). For the medullary patterns, we took photos of mainly the shield region of each guard hair. The cuticular and medullary patterns cited for the studied species follow the nomenclature and definitions proposed by Quadros \& Monteiro-Filho (2006a). To describe the patterns found, we used photomicrographs, descriptions and drawings of the works of Quadros \& Monteiro-Filho (2006b). Subsequently, the images obtained from these slides were compared with a reference collection of hair microstructural images of fifty mammal species obtained from museums, the university Collections (LEVE - Laboratory of Vertebrate Ecology - University Federal of São João del Rei), keys contained in published articles and identification guides (Quadros \& Monteiro-Filho 2010, Miranda et al. 2013).

\subsection{Data analysis}

We identified prey hairs according to six different categories: i. Hair microstructure (cuticle and medulla); ii. Hair microstructure (only medulla); iii. Hair microstructure (cuticle or medulla) and macrostructure (shape, thickness, size or colors); iv. Hair microstructure (cuticle or medulla) and hooves or nails; v. Hair macrostructure and hooves, and vi. Hair macrostructure (shape, thickness, size or colors). We identified predator's hairs by only two categories: i. Hair microstructure (cuticle and medulla) and ii. Hair microstructure (cuticle or medulla) and macrostructure (shape, thickness, size or colors). As the cuticle has only low diagnostic power to differentiate hairs of pumas and jaguars, we associated the identification of cuticle and macrostructure of the hair with tracks and kills found together with the scats. We performed Chi-square goodness-of-fit tests using R (version 4.0.2) to examine the relation between the different categories of the technique of microscopic identification of hairs and the efficiency to identify items in the predators' scats (Octenjak et al. 2020).

\section{Results}

\subsection{Diet analysis by identification categories}

We found a total of 94 scat content items in the Pantanal samples. Of those, we identified 74, being $57(77.0 \%)$ and 17 (23\%) items of 
prey and predators, respectively. We found that the relation between categories of microscopic identification of hairs and the efficiency to identify items in predators' hairs was significant, $\chi 2(5, N=57)=$ 130.26, $\mathrm{p}<0.001$. Hair microstructure (cuticle and medulla) was the most efficient category in identifying hairs of prey species. We identified predators' hairs in 17 (34\%) of the Pantanal samples using category hair microstructure (cuticle or medulla) and macrostructure ( $\mathrm{n}=12$ items, $70.6 \%)$ and hair microstructure (cuticle and medulla) ( $\mathrm{n}=5$ items, $29.4 \%$ ). We did not identify $20(21.3 \%)$ of the total items using our described categories. For the Atlantic Forest samples, we found a total of 93 scat content items. Of those, we identify 84 , being $61(75.3 \%)$ of prey species, and 23 (24.7\%) of predators' species (Table 1). We found that the relation between categories of microscopic identification of hairs and the efficiency to identify items in predators' hairs was significant, $\chi^{2}(5, \mathrm{~N}=61)=82.31, \mathrm{p}<0.001$. As for the Pantanal samples, hair microstructure (cuticle and medulla) was the most efficient category in identifying hairs of prey species of the Atlantic Forest samples. We identified predators' hairs in $23(46 \%)$ of the Atlantic Forest samples mainly using hair microstructure (cuticle and medulla) $(\mathrm{n}=15$ items, $65.2 \%$ ) followed by hair microstructure (cuticle or medulla) and macrostructure ( $\mathrm{n}=8$ items, $34.8 \%$ ) categories. We did not identify 9 (9.7\%) of total items from the described categories. For the Pantanal samples, we identified jaguar, domestic cattle, capybara, paca, Mazama genus and the families Tayassuidae and Muridae using more than one identification category (Table 2). For the Atlantic Forest, we identified capybara, paca, and the Tayassuidae and Muridae families using more than one identification category (Table 3 ).

\subsection{Identification of mammals using microscopic and macroscopic characteristics of hair}

We identified hairs of capybara macroscopically due to their dark brownish tone and large width-thickness. Microscopically, hairs were identified without a medulla in the shield and with a longitudinal division in the axis (Figure 1a). We observed the medullary pattern polygonal on the shaft (Figure 1b) and glandular on the shield (Figure 1c). The cuticle was transverse wavy on the bulb (Figure 1d) and transverse wavy with ornate edges on the shield (Figure 1e). Paca guard hairs were macroscopically identified due to their characteristic aculiform appearance presenting a clear difference in thickness between the short bulb and the marked hair shield. The microstructural patterns found in the medulla were polygonal on the shaft (Figure 1f) and glandular on the shield (Figure 1g). The cuticular pattern observed in paca was irregularly wavy on the bulb (Figure $1 \mathrm{~h}$ ).

Red brocket deer (Mazama gouazoubira Fischer, 1814) and gray brocket deer (Mazama americana Erxleben, 1777) were differentiated by the ornamentation of the most distal portion of the shield. In addition to these features, the gray brocket deer cuticular scale was smoother and more regular on the bulb than the red brocket deer, which was somewhat irregular in orientation and had slight ornamentation on the cuticle edge (Figure 1i). Through these cuticular characteristics and the polygonal pattern (Figure $1 \mathrm{j}$ ), only the red brocket deer species was identified for jaguar samples. For puma samples, we identified deer species to the taxonomic genus level, because besides the occurrence of gray brocket deer and red brocket deer in the region, other species such as the Brazilian dwarf brocket deer (Mazama nana Hensel, 1872), the small red brocket deer (Mazama bororo Duarte, 1996), and the pampas deer (Ozotocerus bezoarticus Linnaeus, 1758) may occur in the state of Paraná (Duarte et al. 2012, IUCN 2020). The microstructural patterns of the latter two species have neither been yet described nor differentiated in the literature. In addition, reference collection of hair images showing microstructural patterns utilized in this study did not contain hair and photomicrographs of these species, thus precluding us from further comparisons and limiting our identification to genus level. The marsh deer (Blastocerus dichotomus Illiger, 1815) was identified by visual patterns of the guard hair as the reddish color and the wavy appearance on the shield. The microstructural patterns presented a polygonal pattern in the medulla (Figure $1 \mathrm{k}$ ) and transverse wavy pattern in the cuticle (Figure 11).

The two species of the genus Tayassuidae, the white-lipped peccary and the collared peccary could not be distinguished from each other by the cuticular and medullary patterns. For both species, the cuticle presented a transverse wavy pattern in the bulb (Figure $1 \mathrm{~m}$ ) and the medulla was cordonal in the shield (Figure 1n). In this case, the hair identification technique was effective in identifying the hair of wild pigs only at the family level.

We distinguished predators' hairs from their prey by cuticular and medullary patterns and macroscopic characteristics associated with the size, shape, thickness, and colors of hairs. For the jaguar, the medulla was trabecular, narrow, and with fringed edges (Figure 10). For the puma, the medulla was trabecular, wide, and with fringed edges (Figure $1 p)$. The cuticular pattern observed in both species was transverse wavy with smooth edges on the bulb (Figure 1q and 1r). In the samples from Paraná, we identified pumas' hairs associating cuticular and medullary patterns. In samples from Pantanal, we identified jaguar's hairs by

Table 1. Percentage of occurrence of prey items found in scat samples from the Pantanal of Mato Grosso do Sul State and Atlantic Forest of Paraná State, according to the identification of categories.

\begin{tabular}{|c|c|c|}
\hline Categories of prey identification & Pantanal $(N=57)$ & Atlantic Forest $(\mathrm{N}=61)$ \\
\hline Hair microstructure (cuticle and medulla) & $68.42(39)$ & $52.45(32)$ \\
\hline Hair microstructure (only medulla) & 0 & $1.64(1)$ \\
\hline Hair microstructure (cuticle and medulla) and hooves or nails & 0 & $6.56(4)$ \\
\hline Hair macrostructure and hooves & $1.75(1)$ & 0 \\
\hline
\end{tabular}


Microstructure of hairs

Table 2. Proportion of prey and predator items of samples from the Pantanal according to categories of identification. N= number of scat content items.

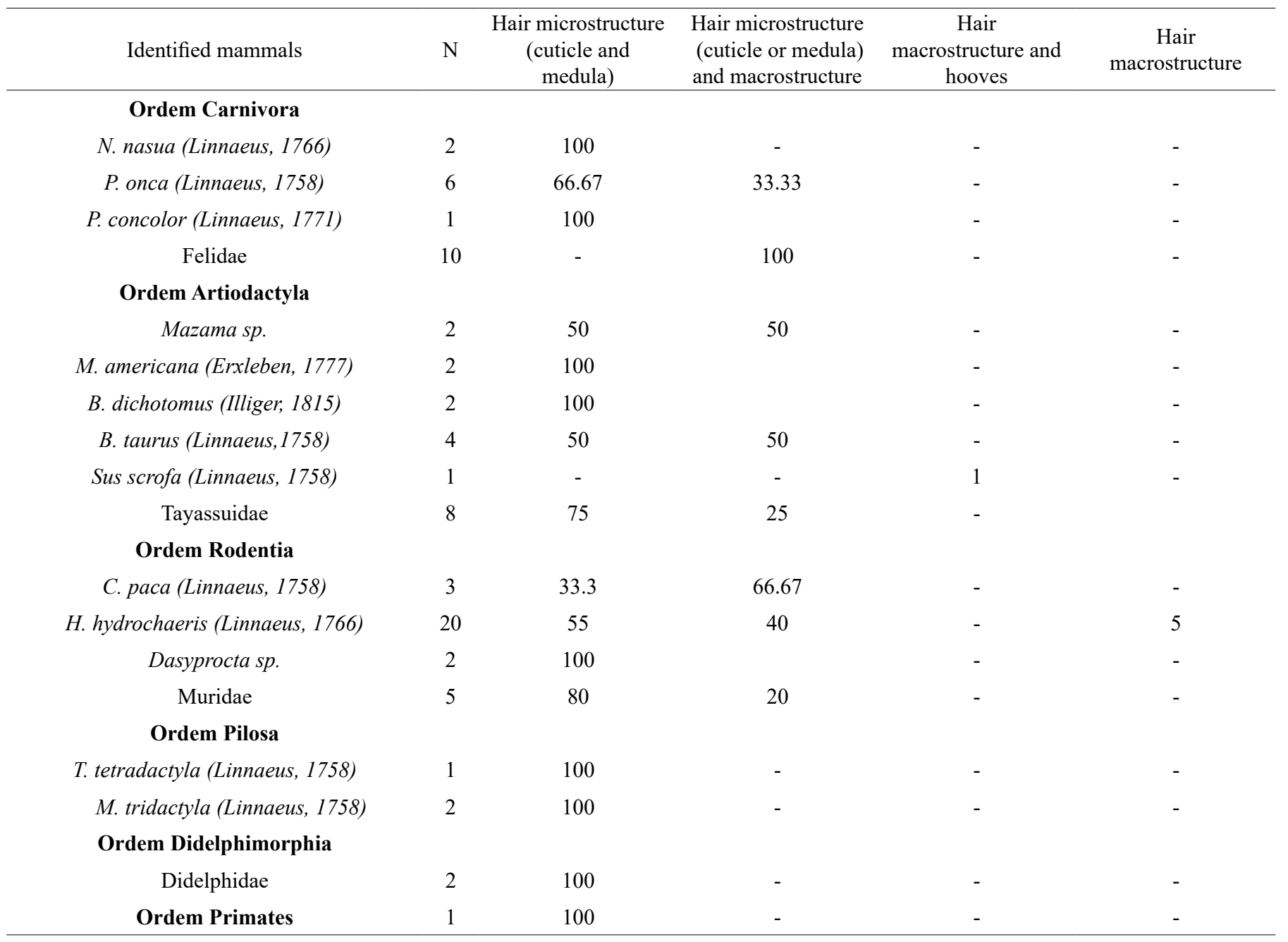

cuticular and medullary patterns obtained together or associated with cuticular patterns, macroscopic characteristics and evidence found in the field such as tracks and kills.

Domestic cattle (Bos taurus Linnaeus, 1758) was identified for presenting large amounts of white hair and the presence of leather in the samples. In addition to the macroscopic aspects of the hair, this specie was identified by the amorphous pattern of the medulla in the shield (Figure 1s) and transverse wavy cuticle in the bulb (Figure 1t). Tapir was microscopically identified by transverse wavy cuticle (Figure 1u) and medulla trabecular (Figure 1v) and the presence of a characteristic nail. Domestic pig (Sus scrofa Linnaeus, 1758) was also macroscopically identified by thick and black hairs and the presence of characteristic hoof. The cuticular impressions of the hair were uneven, precluding us to characterize the cuticular patterns.

Procyonids were identified by amorphous medullar patterns (Figure 2a) and irregular wavy cuticle pattern for the crab eating raccoon (Procyon cancrivorus Cuvier, 1798) (Figure 2b) and the coati (N. nasua Linnaeus, 1766) (Figure 2c). The genus Dasyprocta was identified by the alveolar medulla (Figure $2 \mathrm{~d}$ ) and transverse wavy cuticle with smooth edges in the bulb (Figure $2 \mathrm{~h}$ ). The southern tamandua (T. tetradactyla Linnaeus, 1758) was identified without medulla in the shield (Figure 2e) and with an ornate transverse wavy cuticle (Figure 2f). The giant anteater (M. tridactyla Linnaeus, 1758) was also identified without medulla on the shield, but with a smooth edge transverse wavy cuticle on the bulb (Figure 2g).

The orders Muridae and Didelphidae were identified with medulla alveolar (Figure 2i) and literary, respectively (Figure 21), and both with petal cuticle (Figure $2 \mathrm{j}$ and Figure $2 \mathrm{k}$ ). The order Primates was identified by the discontinuous uniseriate medullary pattern (Figure $2 \mathrm{~m}-\mathrm{n}$ ) in the hair shield and cuticle with a transverse wavy pattern in the bulb (Figure 2o) and transverse wavy with ornamented edges in the shield (Figure 2p).

\section{Discussion}

In our study, most prey identification at species level was only possible when we associated the hair microstructural patterns with its macroscopic characteristics, such as shape, thickness, size or color. In addition, it was possible to diagnose predator's hair when present, using cuticular and medullary patterns together, associating cuticular or medullary patterns with hair macroscopic characteristics. Although the technique was efficient in identifying most species, some limitations in 
Table 3. Proportion of prey and predator items of samples from the Atlantic Forest of Paraná according to the identification categories. $\mathrm{N}=$ number of items.

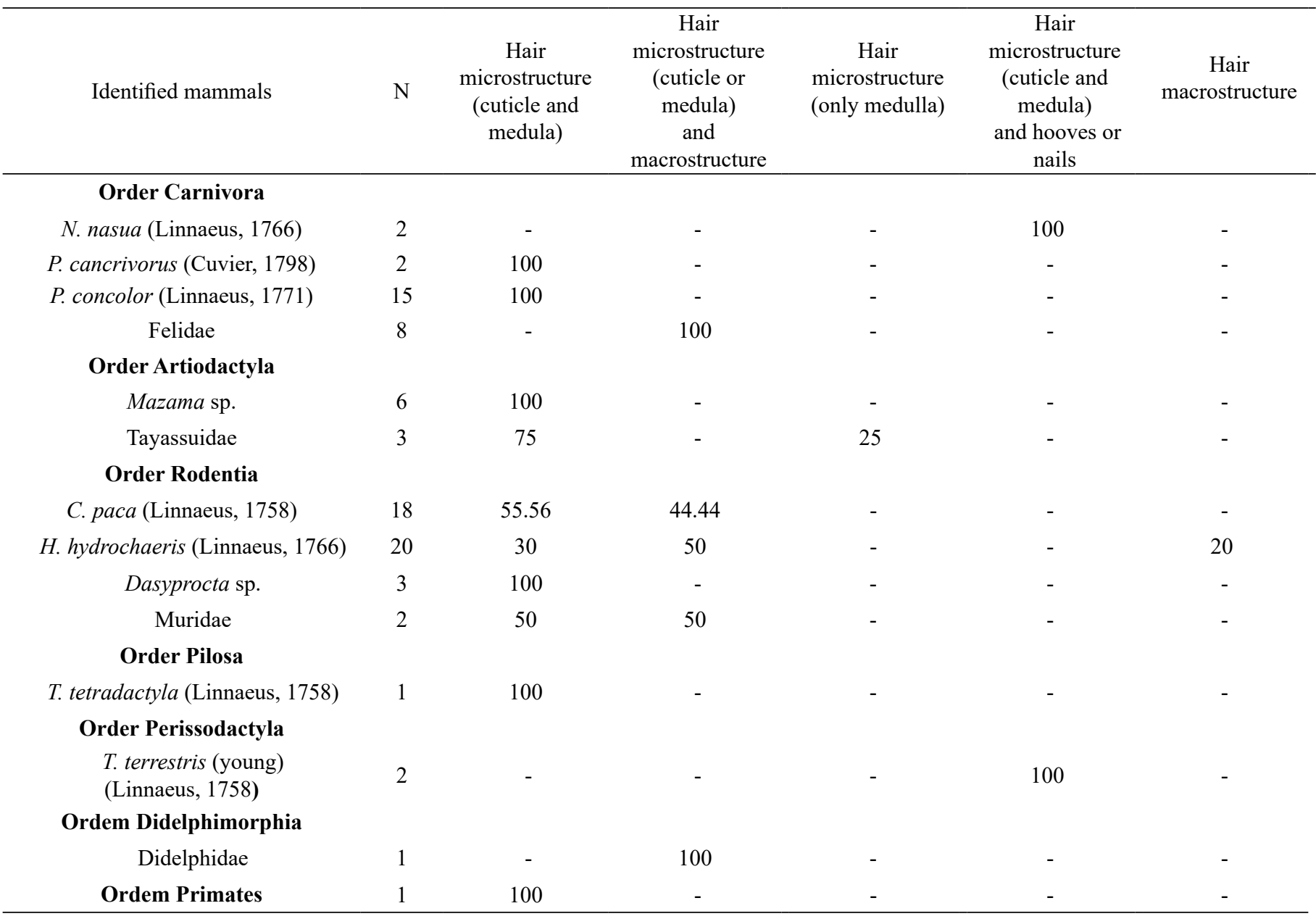

obtaining microstructural patterns of hairs are important. For instance, hairs of capybara were identified using more categories than other species because of the low efficiency in clearly obtaining the medullary and cuticular patterns described in the literature for this species (Quadros $\&$ Monteiro-Filho 2010). Thus, one of the obtained patterns (cuticular or medullary) together with the hair macroscopic characters or even only these macroscopic characters of the hair, were necessary to identify the species. The polygonal medullary pattern for capybaras, not identified by Quadros \& Monteiro-Filho (2010), corroborates the pattern found in other studies (Penna 2009).

It was not possible to differentiate species of Tayassuidae family as there is overlap of cuticle and medulla characteristics between collared peccary and white-lipped peccary. For this family, macroscopic identification together with medullary microestructure of the hair became important when it was not possible to obtain the characteristic cuticular pattern of the family. For species of the Tayassuidade family, the macrostructure of the hair should be used with caution. Although not the same, the shape, thickness, and color of the hair can be confused with these same characteristics of giant anteater hair. Thus, we believe that only the hair macrostructure is not recommended to diagnose the presence of one of the Tayassuidae species (or both) or to tell them apart from the giant anteater. Other techniques, such as morphometric analysis, cryosectioning technique, and cross-sections may be necessary to visualize possible differences (Felix et al. 2019, Mandoreba et al. 2019), but these techniques can be costly and unavailable for most field studies.

The presence of tapir hairs in one of the puma samples was important because of the uniqueness of this finding in puma's diet. In places where pumas and tapir live in sympatry, predation of tapir by pumas is a rare event (Azevedo et al. 2016). Failure to identify tapirs by medullary patterns may be related to the type of hair in the sample. From the observed medullary pattern and the morphological aspect of the hair, it can be inferred that the hairs analyzed were probably under hairs, which are predominant in young individuals. Thus, it is likely the identification of other patterns than those cited in the literature, because those of young individuals (under hairs) are not commonly used for identification purposes (Quadros \& Monteiro-Filho 2006a).

The order Primates was identified in both samples with very low relative frequency of occurrence. This result corroborates what has been found in other studies that also indicated that primates are not frequently consumed by jaguars (Azevedo 2008, Martins et al. 2008). The macroscopic appearance of hairs was not used in the identification, 

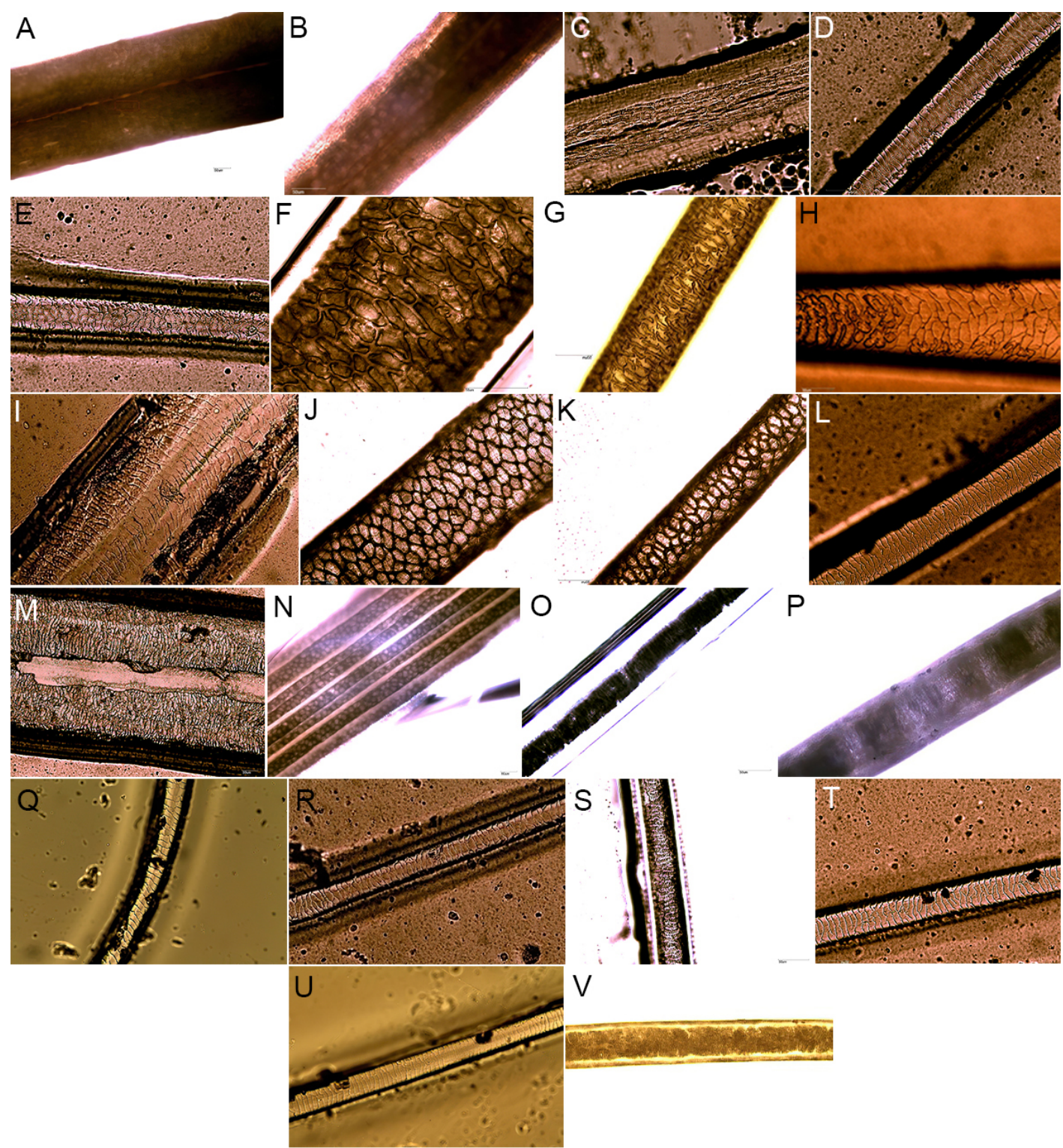

$\mathrm{V}$
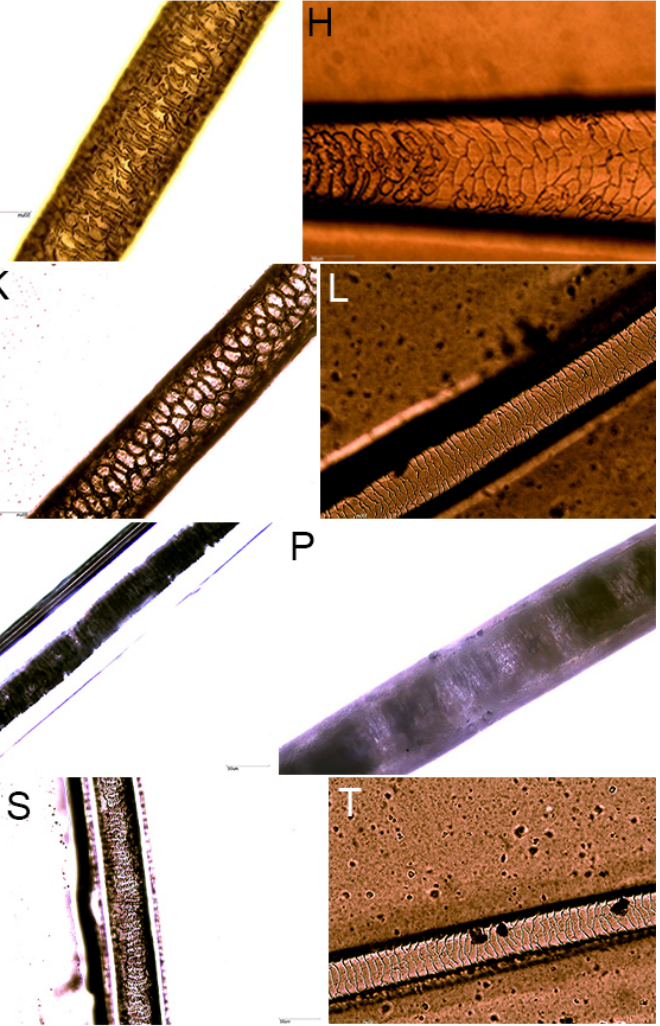

Figure 1: Microscopic identification of hairs of species, genus and orders of mammals using cuticular and medullary patterns. 1a-c medulla of Capybara (H. hydrochaeris -200x); 1d-e cuticle of Capybara (200x); 1f medulla of Paca (C.paca- 400x); 1g medulla of Paca (200x); $1 \mathrm{~h}$ cuticle of Paca (200x); $1 \mathrm{i}$ cuticle of Red brocket deer (Mazama gouazoubira - 200x); $1 \mathrm{j}$ medulla of Red brocket deer (200x); 1k medulla of Marsh deer (B. dichotomus- 400x); 11. cuticle of Marsh deer (200x); 1m cuticle of Tayassuidae (100x); 1n medulla of Tayassuidae (100x); 10 medulla of Puma (Puma concolor - 200x); 1p medulla of Jaguar (Panthera onca - 200x) 1q cuticle of Puma (200X); 1r cuticle of Jaguar (200x); 1s medulla of Bos taurus (200x); 1t cuticle of Bos taurus (200x); 1u cuticle of Tapir (Tapirus terrestris - 200x); 1v medulla of Tapir (200x).

because the visual characteristics of these hairs indicated a wide possibility of potential prey species. Therefore, hairs from the order Primates were only identified through the microstructural patterns.

We should be cautions when analyzing and identifying the microstructures of guard hairs of the order Artiodactyla, as species are differentiated by subtle characteristics that are not easily recognized. Vázquez et al. (2000) studying hairs of red and gray brocket deer could not differentiate them based on the medullary and cuticular patterns of the guard hairs. However, studies that included analysis of hairs from artiodactyls from other parts of the world reported subtle differences between hair microstructures such as the borders' ornamentation of the cuticle and the distance between the borders (De Marinis \& Asprea 2006). Thus, the correct identification of these species requires clear cuticular patterns along with the characteristic polygonal medullary pattern.

The identification of feline hairs is also quite complicated, thus difficulting the differentiation of species. There are subtle differences among Brazilian feline hair microstructures but overlapping morphological patterns may render this technique inaccurate for scientific applications (Vanstreels et al. 2010, Rinaldi et al. 2015, Alberts et al. 2017). In this study, puma and jaguar medullary patterns were different across the ratio of medulla width to maximum hair width. In 


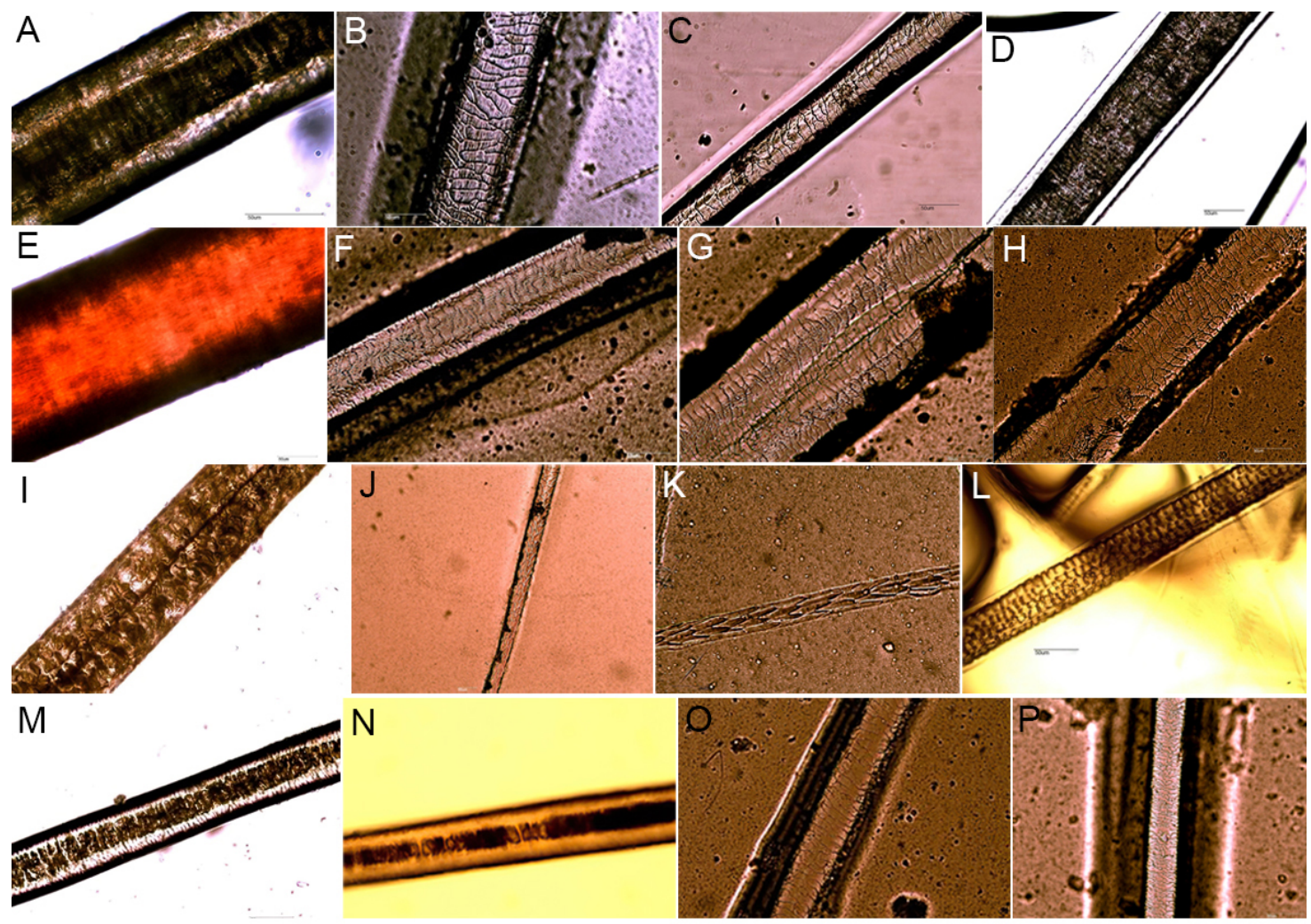

Figure 2: Microscopic identification of hairs of species, genus and orders of mammals using cuticular and medullary patterns (200x). 2a medulla of Procyonids (200x); $2 \mathrm{~b}$ cuticle of Crab eating raccoon (Procyon cancrivorus - 200x); 2c cuticle of Coati ( $N$. nasua - 200x); 2d. medulla of Dasyprocta (200x); 2e medulla of Southern tamandua (T. tetradactyla - 200x) and the Giant anteater (M. tridactyla); $2 \mathrm{f}$ cuticle of Southern tamandua (T. tetradactyla); $2 \mathrm{~g}$ cuticle of Giant anteater (M. tridactyla); $2 \mathrm{~h}$; cuticle of Dasyprocta (200x); $2 \mathrm{i}$ medulla of Muridae (200x); $\mathrm{j}$. cuticle of Muridae (100x); 2k. cuticle of Didelphidae (200x); 21 medulla of Didelphidae (200x); 2m-n medulla of Primates (200x); 2o-p cuticle of Primates (200x).

some samples, it was not possible to obtain the predator's medullary pattern, because of the small quantities of thin and small hairs. Thus, the use of diaphanizers can hinder visualization of the medullary pattern of the threads. In this case, we used the cuticular pattern wavy and transversal and macroscopic hair characteristics such as size, shape, thickness, and banding of colors. These characteristics indicated that hairs would belong only to a puma or a jaguar. For the Pantanal samples, we also found one sample containing hairs of puma, the other large predator that inhabits the surveyed site. This finding could indicate an event of intraguild predation (i.e. predation between two potential competing predator species, Arim \& Marquet 2004) or that one of them may have eaten the recently dead carcass of the other one. In our study, we used tracks of adult individuals or recent dead carcasses associated with scats to minimize chances of collecting scats of small felid species.

Finally, procyonid species (crab eating raccoon and coati) were mainly identified and differentiated by medullary patterns, as both species had an irregular wavy cuticular pattern on the hair shaft. For coatis, the nails found in the samples became indispensable for identification when medullary patterns could not be visualized.

\section{Conclusion}

The microscopic hair identification technique using cuticular and medullary patterns was efficient to identify different taxonomic levels, with most identifications reaching the species level. However, the methodological protocol was not fully effective to obtain all microstructural hair patterns of the mammals presented in our samples. The overlapping of microstructural characteristics among guard hairs of different species and the presence of under hairs in the samples limited the hairs identifications to species levels. It is important that studies aiming to investigate dietary patterns of feline predators, combine the use of microscopic and macroscopic technique to improve the efficiency in the identification of hairs of prey and predator species.

\section{Acknowledgments}

We thank the Fundação de Amparo à Pesquisa do Estado de Minas Gerais (FAPEMIG) by support and Laboratory of Animal Ecology (University of São João del Rei) for making the microscope available for this study. We thank Vagner C. Canuto for contributions with data collection. The authors are also grateful to the two anonymous reviewers for helpful comments to the early versions of this manuscript.

\section{Author Contributions}


Fernando Cesar Cascelli de Azevedo: Substantial contribution in the concept and design of the study; contribution to data collection; contribution to manuscript preparation and critical revision. Fernanda Souza: Contribution to data analysis and interpretation; contribution to manuscript preparation.

\section{Conflicts of interest}

The authors declare that they have no conflict of interest related to the publication of this manuscript.

\section{Ethics}

The procedures described in this study have no conflict with the Brazilian Laws regarding the use of animals in scientific research.

\section{References}

ALBERTS, C. C., SARANHOLI, B. H., FREI, F. \& GALETTI, P. M. 2017 Comparing hair-morphology and molecular methods to identify fecal samples from Neotropical felids. Plos one. 12(9):1-24.

ARIM, M., \& MARQUET, P. 2004. Intraguild predation: a widespread interaction related to species biology. Ecology Letters, 7 (7): 557-564.

AZEVEDO, F.C.C., CANUTO, V., SOUZA, F. \& WIDMER, C. E. 2016. Puma (Puma concolor) predation on tapir (Tapirus terrestris). Biota Neotrop. 16(1): http://dx.doi.org/10.1590/1676-0611-BN-2015-0108 (last access in $11 / 29 / 2019)$.

AZEVEDO, F.C.C. 2008. Food Habits and Livestock Depredation of Sympatric Jaguars and Pumas in the Iguaçú National Park Area, South Brazil. Biotropica. 40(4):494-500.

BORER, E.T., SEABLOOM, E.W., SHURIN, J.B., ANDERSON, K.E., BLANCHETTE. C.A., BROITMAN, B., COOPER S.D. \& HALPERN, S. 2005. What determines the strength of a trophic cascade? Ecology. 86(2): 528-537.

BUENO, A.A. \& MOTTA-JUNIOR, J.C. 2004. Food habits of two syntopic canids, the maned wolf (Chrysocyon brachyurus) and the crab-eating fox (Cerdocyon thous), in southeastern Brazil. Rev. Chil. Hist. Nat. 77(1):5-14.

CARROLL, C., NOSS R.F. \& PAQUET, P.C. 2001. Carnivores as a focal species for conservation planning in the Rocky Moutain Region. Ecol. Appl.11(4):961-980.

DAGNALL, J.L., DUCKETT, J.G. \& GURNELL, J. 1995. A simple negative staining technique for the identification of mammal hairs. J. Zool. 237(4):670-675.

DE MARINIS, A.M., \& ASPREA, A. 2006. Hair identification key of wild and domestic ungulates from southern Europe. Wildlife Biol, 12 (3): 305-320.

DUARTE, J. M.B., VOGLIOTTI, A., ZANETTI, E. S., OLIVEIRA, M. L., TIEPOLO, L. M., RODRIGUES, L. F. \& ALMEIDA, L. B. 2012. Avaliação do risco de extinção de Mazama americana. Biodiversidade Brasileira. 1: 3-11.

ECKSTEIN, R.A. \& HART, E.B.L. 2000. Grooming and control of fleas in cats Appl. Anim. Behav. Sci. 68(2):141-150.

FELIX, G. A., FIORAVANTI, M. C. S., CASSANDRO, M., TORMEN, N., QUADROS, J., JULIANO, R. S., ALVES DO EGITO, A., IVETE DE MOURA, M. \& PIOVEZAN, U. 2019. Bovine breeds identification by trichological analysis. Animals. 9(10): 1:17.

IUCN 2020. The IUCN Red List of Threatened Species. Version 2020-2. https:// www.iucnredlist.org. Downloaded on 17 September 2020.

JUAREZ, K.M. \& MARINHO-FILHO, J. 2002. Diet, habitat use, and home ranges of the sympatric canids in central Brazil. J. Mammal. 83(4): 925-933.
KSHETTRY, A., VAIDYANATHAN, S. \& ATHREYA, V. 2018. Diet Selection of Leopards (Panthera pardus) in a Human-Use Landscape in North-Eastern India. Trop Conserv Sci. 11:1-9.

MANDOREBA, T. Y., CLOETE, K. J., MINNIS-NDIMBA, R. \& KUPIKA, O. L. 2019. A Novel Application of a Cryosectioning Technique to Aid Scat Hair Microanalysis. J. Forensic. Sci.64(4): 1181-1186.

MARTINS, R., QUADROS, J. \& MAZZOLLI, M. 2008. Hábito alimentar e interferência antrópica na atividade de marcação territorial do Puma concolor e Leopardus pardalis (Carnivora: Felidae) e outros carnívoros na Estação Ecológica de Juréia-Itatins, São Paulo, Brasil. Rev. Bras. Zool 25(3): 427-435

MIRANDA, G.H.B., RODRIGUES, F.H.G. \& PAGLIA, A.P.2013.Guia de identificação de pelos-guarda de mamíferos brasileiros para fins forenses. Ciências Forense Editora, Brasília, p.108.

OTENJAK, D., PAĐEN, L., ŠILIĆ, V., RELJIĆ, S., VUKIČEVIĆ, T. T. \& KUSAK, J. 2020. Wolf diet and prey selection in Croatia. Mammal Research. 65:647-654.

PENNA, M.A.H. 2009. Avaliação de características morfológicas e morfométricas dos pelos de roedores da mata atlântica do estado de São Paulo. Tese de Doutorado, Universidade Estadual Paulista "Júlio de Mesquita Filho", São Paulo.

PERILLI, M. L. L., LIMA, F., RODRIGUES, F. H. G. \& CAVALCANTI, S. M. C. 2016. Can scat analysis describe the feeding habits of big cats? A case study with jaguars (Panthera onca) in Southern Pantanal, Brazil. Plos one. 11(3):1-12.

QUADROS, J. \& MONTEIRO-FILHO, E.L.A. 1998a. Effects of digestion, putrefaction and taxidermy processes on Didelphis albiventris hair morphology. J. Zool. 244(3):331-334.

QUADROS, J. \& MONTEIRO-FILHO, E.L.A. 1998b. Morphology of different hair types of Didelphis albiventris and its usage in hair identification. Cien. Cult. 50(5):382-385.

QUADROS, J. 2002. Identificação microscópica de pelos de mamíferos brasileiros e sua aplicação no estudo da dieta de carnívoros. Tese de Doutorado. Departamento de Zoologia, Universidade Federal do Paraná, Paraná.

QUADROS, J. \& MONTEIRO-FILHO, E.L.A. 2006a. Coleta e preparação de pelos de mamíferos para identificação em microscopia ótica. Rev. Bras. Zool. 23 (1): 274-278.

QUADROS, J. \& MONTEIRO-FILHO, E.L.A. 2006b. Revisão conceitual, padrões microestruturais e proposta nomenclatória para os pêlos-guarda de mamíferos brasileiros. Rev. Bras. Zool. 23 (1): 279-292.

QUADROS, J. \& MONTEIRO-FILHO, E.L.A. Identificação dos mamíferos de uma área de floresta atlântica utilizando a microestrutura de pelos-guarda de predadores e presas. 2010. Arq. Mus. Nac. Rio de Janeiro, 68 (1-2): 47-66.

RINALDI, A. R., RODRIGUEZ, F. H., CARVALHO, A. L. \& PASSOS, F. C. 2015. Feeding of small Neotropical felids (Felidae: Carnivora) and trophic niche overlap in antropized mosaic landscape, South Brazilian. Biotemas. 28(4): 155-168.

SANTOS, F., CARBONE, C., WEARN, O.R., ROWCLIFE, J.M., ESPINOSA, S., LIMA, M.G.M.L., AHUMADA, J.A., GONÇALVES, A.L.S., TREVELIN, L.C., ALVARES-LOAYZA, P., SPIORONELLO, W.R., JANSEN, P.A., JUEN, L. \& PERES, C.A. 2019. Prey availability and temporal partitioning modulate felid coexistence in neotropical forests. Plos One 14(3):1-23.

SCHONEWALD-COX, C., AZARI, R. \& BLUME, S. 1991. Scale, variable density and conservation planning for mammalian carnivores. Conserv. Biol. 5(4):491-495

TERBORGH, J.1992. Maintenance of diversity in tropical forests. Biotropica. 24(2):283-292 
TERBORGH, J. LOPES, L., NUNEZ, P.V., RAO, M., SHAHABUDDIN, G., ORIHUELA, G., RIVEROS, M., ASCANTO, R., ADLER, G.H., LAMBERT, T.D. \& BALBAS. L. 2001. Ecological meltdown in tropical predator-free forest fragments. Science. 294(5548):1923-1925.

TIRELLI, F. P., DE FREITAS, T. R. O., MICHALSKI, F., PERCEQUILLO, A. R. \& EIZIRIK, E. 2019. Using reliable predator identification to investigate feeding habits of Neotropical carnivores (Mammalia, Carnivora) in a deforestation frontier of the Brazilian Amazon. Mammalia. 83(5):415-427.

TORTATO, M.A. 2009. Disponibilidade e uso de presas na dieta do gato-domato-pequeno, Leopardus tigrinus (Schreber, 1775) em áreas de restinga no sul do Brasil. Dissertação de mestrado. Universidade Federal do Paraná, Paraná.
VANSTREELS, R.E.T., RAMALHO, F.P. \& ADANIA, C.H. 2010. Guard-hair microstructure of Brazilian felids: considerations for species identification. Biota Neotrop.10 (1): http://www.biotaneotropica.org.br/v10n1/en/ abstract?article+bn00910012010 (last access in 25/11/2019).

WOLFE, A. \& LONG, A. M. 1997. Distinguishing between the hair fibers of the rabbit and the mountain hare in scats of the red fox. J. Zool. 242(2):370-375.

Received: $21 / 05 / 2020$

Revised: 12/10/2020

Accepted: $23 / 10 / 2020$

Published online: 14/12/2020 